\title{
Analysis of health behaviors and the significance of health among occupationally-active persons
}

\author{
Analiza zachowań zdrowotnych oraz znaczenie zdrowia wśród osób aktywnych zawodowo
}

\section{Marta Kordyzon ${ }^{1}$, Grażyna Nowak-Starz²}

'Uniwersytet Jana Kochanowskiego w Kielcach, Wydział Lekarski i Nauk o Zdrowiu, Instytut Pielęgniarstwa i Położnictwa/ Jan Kochanowski University in Kielce, Faculty of Medicine and Health Sciences, Institute of Nursing and Obstetrics 2Uniwersytet Jana Kochanowskiego w Kielcach, Wydział Lekarski i Nauk o Zdrowiu, Instytut Zdrowia Publicznego/ Jan Kochanowski University in Kielce, Faculty of Medicine and Health Sciences, Institute of Public Health

CORRESPONDING AUTHOR/AUTOR DO KORESPONDENCJ:

Marta Kordyzon

ul. Tumlińska 11, 26-085 Miedziana Góra e-mail: martasiwek8@gmail.com

STRESZCZENIE

Słowa kluczowe:

ABSTRACT

\section{ANALIZA ZACHOWAÑ ZDROWOTNYCH ORAZ ZNACZENIE ZDROWIA WŚRÓD OSÓB AKTYWNYCH ZAWODOWO}

Cel pracy. Celem badań była ocena zachowań zdrowotnych oraz pozytywnych elementów wymiarów zdrowia fizycznego, psychicznego i społecznego.

Materiał i metody. Badania przeprowadzono wśród osób pracujących, które w miesiącu luty -marzec 2018 zgłosiły się na badania okresowe do Poradni Medycyny Pracy w NZOZ w Kielcach. W badaniu wykorzystano dwa standaryzowane kwestionariusze ankiet: Inwentarz Zachowań Zdrowotnych oraz Listę Kryteriów Zdrowia.

Wyniki. Kobiety uzyskały wyższe wyniki w skali IZZ niż mężczyźni. Ponadto ważną determinantą zachowań zdrowotnych okazało się wykształcenie. Badani z wykształceniem podstawowym prezentują niższy poziom zachowań zdrowotnych niż badani z wykształceniem wyższym. $Z$ analizy badań własnych wynika, iż badani najwyższą wagę przypisują zdrowiu definiowanemu jako stan, właściwość oraz cel. Dla badanych bycie zdrowym oznacza: , czuć się dobrze”, ,nie odczuwać żadnych dolegliwości bólowych”, ,, mieć sprawne wszystkie części ciała”, ,, akceptować siebie i znać swoje możliwości" czy „nie chorować, najwyżej rzadko na grypę lub niestrawność". Wnioski. Główne działania wieloletniej edukacji zdrowotnej w miejscu pracy powinny uwzględniać indywidualne zapotrzebowania pracowników, a szczególnie te elementy, które w ocenie pracowników stanowią ich własną definicje zdrowia oraz uwarunkowań zdrowia.

zdrowie, zachowania zdrowotne, osoby pracujące

Introduction. Health is a positive and superior value for every human being, which we want to maintain and reinforce. Health initiative skills should be developed not only in the adolescence phase, but also in the period of active participation in occupational and private life. Today, important recipients of all educational and health-promoting activities are occupationally-active persons, who reflect the state of health of the whole society through their own state of health.

Aim. The aim of the study was to assess the health behavior of working persons and to obtain opinions on the value of health among occupationally-active persons.

Material and methods. The studies were conducted among working people who, in the months from February to March 2018, reported for periodic examinations to an 0ccupational Medicine Outpatient Clinic in a Nonpublic Healthcare Facility in Kielce. Two standardized questionnaires were used in the study: The Health Behavior Inventory and the List of Health Criteria.

Results. Women score higher on the HBI scale than men. In addition, education proved to be an important determinant of health behaviors. Respondents with primary education present a lower level of health behaviors than those with higher education. The analysis of our own studies shows that the respondents attach the highest importance to health defined as a state, a property and a purpose. For the respondents, being healthy means: "to feel good", "not to feel any pain", "to have all parts of the body in good condition", "to accept oneself and know one's capabilities" or "not to come down with illnesses, maybe with flu or indigestion at most". Conclusions. The main activities of long-term health education in the workplace should take into account the individual needs of workers, especially those elements which, in the workers' assessment, constitute their own definition of health and health determinants. 


\section{INTRODUCTION}

In today's understanding of health, the definition adopted by the WHO (World Health Organization) plays an important role. Not only does it define health as a concept of well-being, but it also characterizes health as a state of diversity, variability and continuity [1]. In addition to the definition of health, the main determinants of health have been identified, the most important of which are: lifestyle, the social and physical environment of life and work, genetic factors or health care. The location of health among such a complex structure of conditions allowed to consider health in the social and ecological model [1-2].

Health, regardless of the way it is defined, is a positive value for every human being, that we want to maintain and constantly reinforce. The potential of a human beings perceived through health enables them comprehensive development and better adaptation to various life and environmental situations. The way we understand and identify with health allows us to decide what choices we make in the context of health behaviors, which then become a component of our lifestyle [1, 3-4].

Health behaviors are activities that aim to maintain and continuously reinforce the individual's health potential. The formation of health behaviors is the result of a socialization process that begins in the family environment and continues throughout life. An important role in shaping health attitudes is played by school, health care, but also social and cultural groups, among which we function [5].

A special role in shaping knowledge about health and developing pro-health skills is assigned to activities in the field of health education or health promotion. Both these processes should accompany people at each stage of their development with the support of appropriate professionals (so-called lifelong learning) [6].

The important recipients of educational activities nowadays are adults, occupationally-active persons. Statistical analyses show that the number of elderly people will significantly increase year on year, reflecting not only the economic condition of our country, but also the state of health of our society. The state of health of occupationally-active persons determines both their quality of life and their ability to fully perform their family, social or professional roles [6-7].

The way people define the concept of health in their daily functioning is determined by various factors. Age, education, the socio-economic situation or the cultural environment of life and work have an impact on the definition of health [1]. The ability to differentiate between actions to serve health depends mainly on the knowledge we possess and acquire in the course of our lives. Health initiative skills should be developed and reinforced not only in the adolescence phase, but also in the period of active participation in occupational life.

The selection of the topic is an attempt to supplement the current state of knowledge in the field of research analyzing health behaviors and the importance of health in the working population. Numerous publications dealing with the issues of health and health protection of occupationally-active persons only prove that the subject is important from a medical, social or even economic perspective. Given the unfavorable demographic outlook for our society, any study attempting to approximate the health profile of the economically active population will make an important contribution to the measures aimed at maintaining or reinforcing the health potential of adults.

\section{AIM}

The aim of the research is to evaluate health behaviors and opinions on the importance of health among occupationally-active persons.

\section{MATERIALS AND METHODS}

The study was conducted in October - November 2017 in a Nonpublic Healthcare Facility in Kielce. The first stage of the study was the random selection of the study group. The study group consisted of occupationally-active persons, representing various work environments, who came to the Occupational Medicine Outpatient Clinic in the above mentioned healthcare facility for periodic examinations. In the next stage of the study the respondents were asked to fill in a questionnaire after a previous explanation of the purpose of the survey. Data on age, sex and education are presented in Table 1.

In order to assess the health behaviors of working persons, the study utilized the standardized Health Behavior Inventory (HBI) questionnaire according to Z. Juczyński. This tool contains 24 statements describing different health behaviors. On the basis of the frequency of particular behaviors indicated by the respondents, it is possible to assess the intensity of behaviors which strengthen health and the degree of intensity of the four categories of health behaviors:

- proper eating habits,

- prophylactic behavior,

- health practices,

- positive mental attitude.

Tab. 1. The profile of the studied group

\begin{tabular}{|c|c|c|c|c|c|c|c|c|}
\hline \multirow{2}{*}{ No. } & \multirow{2}{*}{\multicolumn{2}{|c|}{ Analyzed variables }} & \multicolumn{2}{|c|}{ Women } & \multicolumn{2}{|c|}{ Men } & \multicolumn{2}{|c|}{ Total } \\
\hline & & & $\mathbf{N}$ & $\%$ & $\mathbf{N}$ & $\%$ & $\mathbf{N}$ & $\%$ \\
\hline 1 & \multicolumn{2}{|c|}{ Sex } & 49 & 48.5 & 52 & 51.5 & 101 & 100.0 \\
\hline \multirow{6}{*}{2} & \multirow{6}{*}{ Age } & $18-29$ & 14 & 28.6 & 8 & 15.4 & 22 & 21.8 \\
\hline & & $30-39$ & 15 & 30.6 & 23 & 44.2 & 38 & 37.6 \\
\hline & & $40-49$ & 17 & 34.7 & 12 & 23.1 & 29 & 28.7 \\
\hline & & $50-59$ & 3 & 6.1 & 9 & 17.3 & 12 & 11.9 \\
\hline & & $>60$ & 0 & 0.0 & 0 & 0.0 & 0 & 0.0 \\
\hline & & Total & & 100 & & 100 & & 100 \\
\hline \multirow{5}{*}{3} & \multirow{5}{*}{ Education } & Primary & 0 & 0 & 2 & 3.8 & 2 & 2.0 \\
\hline & & Secondary & 11 & 22.4 & 11 & 21.2 & 22 & 21.8 \\
\hline & & $\begin{array}{l}\text { Secondary } \\
\text { vocational }\end{array}$ & 11 & 22.4 & 19 & 36.5 & 30 & 29.7 \\
\hline & & Higher & 27 & 55.1 & 20 & 38.5 & 47 & 46.5 \\
\hline & & Total & & 100 & & 100 & & 100 \\
\hline
\end{tabular}

Source: author's own materials 
The reliability of the HBI scale used in the study was tested using the Cronbach alpha coefficient, which amounted to 0.85 . Therefore, it should be considered that the reliability of the HBI scale in this paper was very good.

In order to obtain opinions on the value of health among the occupationally-active persons, a standardized questionnaire LHC - List of Health Criteria according to Z. Juczyński was used. The research tool contains 24 positive statements relating to the three dimensions of health: physical, mental and social. Respondents mark their selections, indicating at the same time which statements are important to them in the health assessment. At the end of the survey, the respondent must prioritize the statements from the most important to the least important.

\section{RESULTS}

The number of 101 people took part in the study. Both women $(48.5 \%, \mathrm{n}=49)$ and men $(51.5 \%, \mathrm{n}=52)$ constituted almost half of the surveyed group. The highest percentage of the respondents were people aged 30-39 (37.6\%, $\mathrm{n}=38)$ and $40-49(28.7 \%, \mathrm{n}=29)$. The smallest group were respondents aged over $60(11.9 \%, \mathrm{n}=12)$. The studied group was dominated by people with higher education $(46.5 \%, \mathrm{n}=47)$ and secondary vocational education $(29.7 \%, \mathrm{n}=30)$. Only two of the respondents declared that they had a primary education.

In order to answer the research questions posed: (Does sex, age and education level of the working persons influence the declared health behaviors? How does sex, age and education level of working persons influence their definition of health values?), statistical analyses were carried out using the IBM SPSS Statistics 23 software.

In the first stage of the study, it was decided to verify the hypothesis that the intensity of the health behaviors declared by the respondents is related to their level of education, age group and sex. The results were statistically significant for the main outcomes of all variables: sex: $\mathrm{p}=0.029$, age group: $\mathrm{p}<0.001$, education: $\mathrm{p}=0.003$.

The analysis of the study showed that women score significantly higher $(\mathrm{p}<0.001)$ on the HBI scale than men. However, this did not happen in all age groups and not in people with every education level. According to the research, in the group of people aged 18-29 with secondary education and in the group of people aged 50-59 with higher education, men scored higher on the HBI scale $(\mathrm{p}=0.035$ and $\mathrm{p}=0.009$ respectively).

The lowest results on the HBI scale were obtained by people with primary education, while in the group of older people (age group 50-59), the highest results were obtained among people with higher education. It was also noted that people aged 18-29 and 50-59 obtained by far the highest results. They were significantly higher $(\mathrm{p}=0.041$ and $\mathrm{p}<0.001$, respectively) than the results obtained in the age group 30-39 years. The results are presented in Table 2.

The research also showed that a strong determinant of health behaviors is the education level of the studied persons. Both women and men with higher education do not differ in the declared proper eating habits. These differen- ces are in turn visible among people with lower education. Moreover, women, regardless of their education, participate more often in preventive examinations $(\mathrm{p}<0.001)$ and implement health practices $(\mathrm{p}=0.048)$ as opposed to men. Studies have shown that both women and men present the same level of behaviors in terms of mental attitudes. The results are presented in Table 3.

The next stage of the research was to learn about the importance of health among occupationally-active persons. The analysis of research results showed that health is most often defined as a state, a property and a purpose. Respondents of all sexes, ages and educational backgrounds considered the statement "I feel happy most of the time" and "Not to feel any physical ailments" to be important when it comes to interpreting the concept of health.

Tab. 2. Average results of health behaviors in women and men depending on education level and age

\begin{tabular}{|c|c|c|c|}
\hline Age & Education & Women & Men \\
\hline & & Median/M & Median/M \\
\hline \multirow{4}{*}{$18-29$} & Primary & & \\
\hline & Secondary & 81 & 97.5 \\
\hline & Vocational & & 82 \\
\hline & Higher & 87.9 & 95 \\
\hline \multirow{4}{*}{$30-39$} & Primary & & \\
\hline & Secondary & 86.33 & 63 \\
\hline & Vocational & 97.33 & 71.25 \\
\hline & Higher & 86.44 & 79.69 \\
\hline \multirow{4}{*}{$40-49$} & Primary & & 49 \\
\hline & Secondary & 78.2 & 72.5 \\
\hline & Vocational & 88.4 & 74.5 \\
\hline & Higher & 92 & 47 \\
\hline \multirow{4}{*}{$50-59$} & Primary & & \\
\hline & Secondary & & 74 \\
\hline & Vocational & 87.5 & 81.6 \\
\hline & Higher & 90 & 119 \\
\hline
\end{tabular}

Source: author's own materials

Tab. 3. Average results of health behaviors depending on the sex and education of the respondents

\begin{tabular}{|c|c|c|c|c|c|c|c|}
\hline \multirow{2}{*}{\multicolumn{2}{|c|}{$\begin{array}{c}\text { Health } \\
\text { behaviours }\end{array}$}} & \multirow{2}{*}{$\begin{array}{c}\begin{array}{c}\text { Health } \\
\text { behaviour } \\
\text { inventory }\end{array} \\
M \\
\end{array}$} & \multirow{2}{*}{$\begin{array}{c}\text { Correct } \\
\text { eating } \\
\text { habits }\end{array}$} & \multirow{2}{*}{\begin{tabular}{|c|}
$\begin{array}{l}\text { Preventive } \\
\text { behaviours }\end{array}$ \\
M \\
\end{tabular}} & \multirow{2}{*}{\begin{tabular}{|c|}
$\begin{array}{c}\text { Positive } \\
\text { mental } \\
\text { attitude }\end{array}$ \\
M \\
\end{tabular}} & \multirow{2}{*}{\begin{tabular}{|c|}
$\begin{array}{c}\text { Health } \\
\text { practices }\end{array}$ \\
$M$
\end{tabular}} & \multirow[t]{2}{*}{ Total } \\
\hline & & & & & & & \\
\hline & \multicolumn{7}{|l|}{ Primary } \\
\hline & Secondary & 5.00 & 3.43 & 3.46 & 3.36 & 3.28 & 18.53 \\
\hline & Vocational & 6.50 & 4.03 & 3.68 & 4.18 & 3.25 & 21.64 \\
\hline & High & 6.11 & 3.78 & 3.63 & 3.82 & 3.53 & 20.87 \\
\hline & Total & 17.61 & 11.24 & 10.77 & 11.36 & 10.06 & 61.04 \\
\hline & Primary & 1.00 & 1.83 & 2.17 & 2.17 & 2.00 & 9.17 \\
\hline & Secondary & 5.00 & 2.89 & 3.02 & 3.65 & 3.03 & 17.59 \\
\hline & Vocational & 5.21 & 2.95 & 2.83 & 3.88 & 2.97 & 17.84 \\
\hline & High & 6.30 & 3.48 & 3.37 & 4.01 & 3.32 & 20.48 \\
\hline & Total & 17.51 & 11.15 & 11.39 & 13.71 & 11.32 & 65.08 \\
\hline
\end{tabular}

Source: author's own materials 
Next, it was examined whether the respondents, depending on age, sex and education level, differed in the way of defining health through a term such as "Not to come down with illnesses, maybe with flu or indigestion at most". In this case the result was statistically significant for the main outcome of the education variable $(p=0.008)$. Health understood as the "absence of diseases" was statistically significantly more often declared by people with vocational education $(p=0.006)$ than by people with higher education (Figure 1). In addition, it can be stated that in the age group 30-39 years men ( $\mathrm{p}=0.005)$ perceive health as a state without diseases more than women. A different situation can be observed in the group of 40-49 year olds. In this age group, women $(p=0.003)$ perceive health as a period of life without disease more than men (Figure 2).

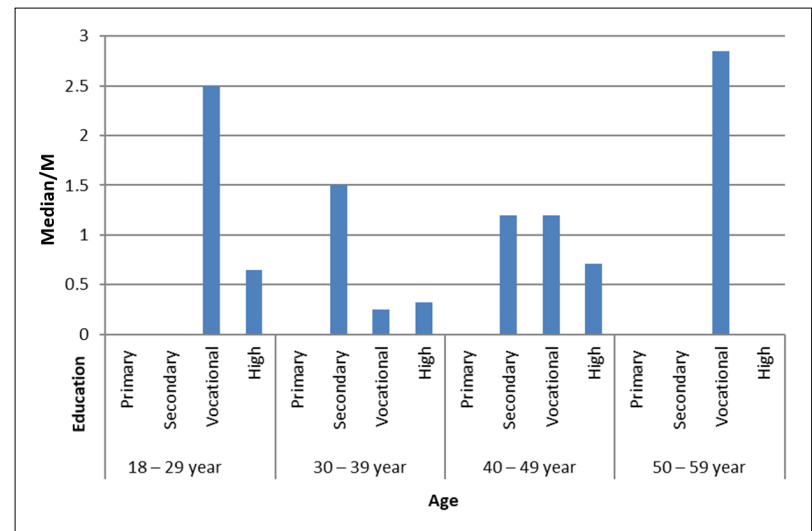

Fig 1. Perception of the absence of diseases as health property by the respondents depending on their education and age

Source: author's own materials

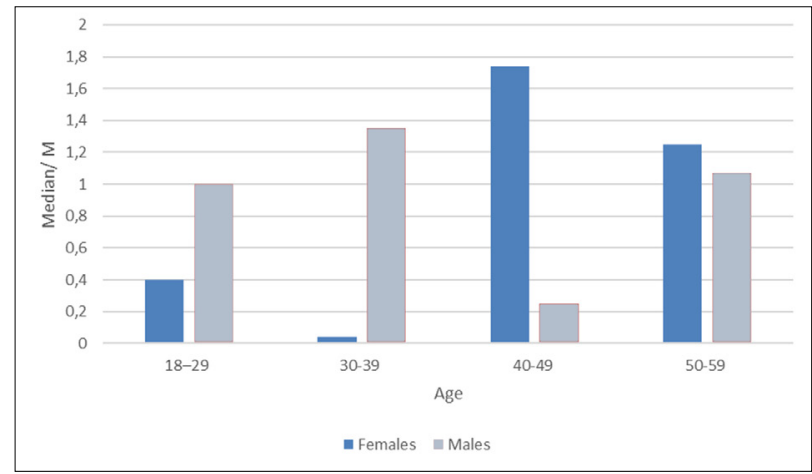

Fig 2. Perception of the absence of diseases as health properties by women depending on their age group

Source: author's own materials

Respondents also stated that the term referring to the fitness of all body parts is important in defining health (this is the 20th statement on the LHC). This statement proved to be much more important for older people compared to those aged 18-29. Moreover, this property is more often declared by respondents with secondary or secondary vocational education in relation to people with higher education (Figure 3). The perception of the fitness of all parts of the body as a characteristic feature of health is different among women and men aged 30-39 years. Women in this age group perceive the statement no. 20 on the LHC as important for the assessment of health property statistically more $(\mathrm{p}=0.002)$ than men.

The study also showed that the education of the respondents influences the way of defining health through the property - "Feeling good". People with primary education $(M=1.03)$ are more likely to describe health as a condition in which they feel comfortable compared to people with secondary education $(\mathrm{M}=1.18)$, vocational education $(M=1.03)$ or higher education $(M=0.75)$. The results are presented in Figure 4.

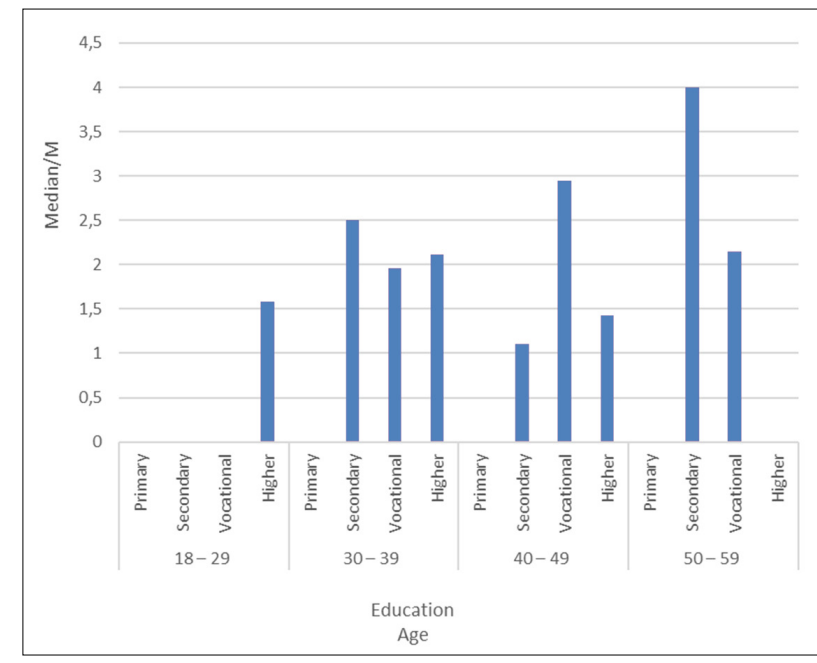

Fig 3. Perception of the efficiency of all parts of the body as health property by the studied depending on education level and age

Source: author's own materials

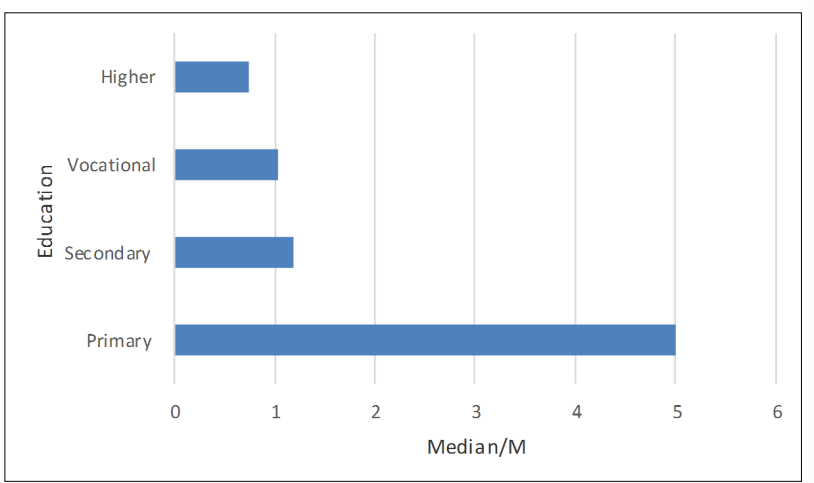

Fig 4. The importance of well-being as a condition defining health in the assessment of subjects depending on their education level

Source: author's own materials

\section{DISCUSSION}

Determining what it means for a human being to "be healthy" can sometimes be difficult and ambiguous. The way health is defined and valued is determined by age, sex, education level and other factors, among others social, cultural or religious ones. It is currently estimated that there are around 120 definitions of health. The main problem with the term "health" is the fact that the way of defining it depends on the aims, circumstances or intentions of the creators themselves. Differences in the way health is defined also result from numerous health determinants, including socio-cultural and socio-economic ones. 
An attempt to evaluate and redefine health is most often made at the time of illness or disability. The health behaviors that determine our physical and mental health take on a new meaning then.

The results of the conducted research indicate that women score higher on the HBI scale than men. In addition, education proved to be an important determinant of health behaviors of the respondents. Respondents with primary education present a lower level of health behaviors in relation to people with higher education.

Different results in comparison to own research were obtained in the study of Arendt A. et al. [8], who analyzed the health behaviors of men over 40 years of age. The results of the above research indicate that education does not significantly influence the health behaviors presented by men, and the level of their health behaviors is at an average level. Also, the results of a study conducted in 2016 among patients treated at the Obesity Treatment Clinic showed that it was men who declared practices related to proper nutrition more often than women. Correspondingly, it was an average result in men and a low result in women [9].

The studies conducted in 2009 by Andruszkiewicz A. et al. among people addicted to nicotine (including 104 men) indicate a low level of declared health behaviors of men as opposed to women, which is consistent with the results of own research [10]. Similar results were also obtained in a study conducted among hospitalized patients of the Hospital Emergency Ward in Bydgoszcz, what shows that among male patients, there are lower values of health behaviors than in women [11]. Research conducted among participants of the University of the Third Age also shows that sex determines health behaviors. In the Cieślak - Zadworna M. and Ogińska-Bulik N. studies, women achieved higher health behavior results than men [12] in the Health Behavior Inventory.

Different results, as compared to own research, were obtained in the studies of Kaczyńska-Witkowska A. et al. The quoted authors studied health behaviors and attitudes towards the health of physically active women. At that time, the results on the HBI scale for women assumed an average level in the study [13].

Own studies shed some light to the correlation between the sex of the respondents and the level of health behaviors (women declare positive health behaviors more often). These results are consistent with other reports, which indicate that women are more willing to present pro-healthy behaviors, related, among others, to a healthier diet [14].

According to studies evaluating the relationships between particular categories of health behaviors of elderly people and socio-demographic variables, only education influences the observed differences in the declared health behaviors. As in own research, a low level of health behaviors is more frequently observed among people with primary education [15].

Own research results show that women more often than men implement health practices and participate in preventive examinations. Similar results were obtained in studies conducted by Grochans E. et al. [16]. In the studies cited above, women were twice as likely to declare behaviors from the field of health practices and prophylactic practices.
In literature, education is described as a factor strongly determining the health behaviors of the population [17-18]. In the article by Ślusarska and Nowicki we read that higher education correlates with a higher indicator of health behaviors, while people with primary education present a low level of health behaviors. From the above reports it can be concluded that education, understood as a long-term and continuous process, influences the level of knowledge, and thus determines the individual's ability to shape their own health and health behaviors.

Own research included an attempt to establish a link between the age of the respondents and the level of health behaviors. Own research results indicate that a higher level of health behaviors was presented by people aged 18-29 and people over 50 years of age. In a study carried out in 2010, Bednarek A. et al. [19] attempted to analyze the health behaviors of girls and boys of school age. These studies show that both boys and girls show abnormal pro-health behaviors, and behaviors associated with poor nutrition and low activity are more common among girls. Despite the fact that younger age groups are analyzed in these studies, the role of health education in the adolescence period should be taken into account. Patterns of health behaviors acquired during primary education may have a huge impact on shaping health in later years. Both the school as an institution and the working environment play an important role in shaping good health habits and creating greater responsibility for one's own health.

The analysis of our own studies shows that the respondents attach the highest importance to health defined as a state, a property and a purpose. For the respondents, being healthy means feeling good, not feeling any pain, have all parts of the body in good shape, accepting oneself, knowing one's capabilities or not being ill.

The research conducted by Kozieł et al. [20] and Naszydłowska et al. [21] among students of the Świętokrzyskie School of Medicine indicate that the respondents hold health, which is defined as a value and a process, in high regard. The above research also shows that for the students surveyed, having all parts of the body in good shape is the most appropriate state to describe health. Also, studies by Piasecka $H$. et al. [22], assessing the value of health in the opinion of the student community, showed that young people attached greater importance to the statement: "Have all parts of the body in good shape". The above reports are contrary to the results of own research, in which older people defined health through the category of fitness of all body parts more often.

Own research results indicate that the term "Not being ill" is particularly important in defining health for people with lower education. These results are consistent with those presented by Nowicki G. and Ślusarska B. [18]. The research carried out by the quoted authors in 2008 at the Voivodeship Occupational Medicine Center in Lublin showed that for people with basic education, the most important condition describing health is the statement: "Not to come down with illnesses, maybe with flu or indigestion at most". The above research also shows that older people (over 50 years of age) chose the statement "Have all parts of the body in good shape" as a description of 
health more often in comparison to younger people. Own research also suggests that older people were more likely to choose this term in order to define health.

Own research has also shown that men aged from 18 to 39 years are more likely to choose the statement: "Not to come down with illnesses, maybe with flu or indigestion at most" in order to determine the value of health. Similar results were obtained in the studies conducted by Krajewska-Kułak E. et al. [23]. The study conducted among men quoted above shows that out of 24 statements of the List of Health Criteria, the respondents attached the greatest importance to health understood as a condition when they are not ill or rarely ill.

Own research suggests that women, regardless of age and education, attach equal importance to the statement "not to feel any pain". Different results were obtained in the studies of Deluga A. et al. [24], which analyzed the method of health evaluation among nurses. The results of the above studies show that this property closely correlates with age - the higher the age, the higher the rank of the above statement.

\section{CONCLUSIONS}

- When analyzing the health behaviors of working persons, it should be stated that education level is the main determinant of health behaviors, which significantly influences individual skills of taking care of health and maintaining the health potential.

- The health profile of the working population indicates that women have higher health behavior outcomes, are more likely to implement health practices and undertake health prevention activities.

- Health defined by the properties indicating proper functioning of the body or a state without illnesses is characteristic of older people with lower education.

\section{Analiza zachowań zdrowotnych oraz znaczenie zdrowia wśród osób aktywnych zawodowo}

\section{WPROWADZENIE}

We współczesnym rozumieniu zdrowia dużą rolę odgrywa definicja przyjęta przez WHO (z ang. World Health Organization), zgodnie z którą zdrowie to stan zróżnicowania, zmienności oraz ciągłości [1]. Obok definicji zdrowia określone zostały także główne determinanty zdrowia, wśród których najważniejsze to: styl życia, środowisko społeczne oraz fizyczne życia i pracy, czynniki genetyczne czy ochrona zdrowia. Umiejscowienie zdrowia wśród tak złożonej konstrukcji uwarunkowań pozwoliło rozpatrywać zdrowie w modelu społeczno-ekologicznym $[1,2]$.

Zdrowie niezależnie od sposobu definiowania jest dla każdego człowieka wartością pozytywną, którą chcemy utrzymywać i ciągle wzmacniać. Postrzegany w zdrowiu potencjał człowieka umożliwia mu wszechstronny rozwój oraz lepszą adaptację do różnych sytuacji życiowych i środowiskowych. Sposób w jaki rozumiemy zdrowie i utożsamiamy się z nim pozwala nam decydować o tym, jakich wyborów dokonujemy w kontekście zachowań zdrowotnych, które następnie stają się składową naszego stylu życia $[1,3,4]$.

Zachowania zdrowotne to działania, które mają na celu utrzymanie i ciągłe umacnianie indywidualnego potencjału zdrowotnego. Kształtowanie zachowań zdrowotnych powstaje w procesie socjalizacji, który zaczyna się w środowisku rodzinnym i kontynuowany jest przez całe życie. Ważną rolę w kształtowaniu postaw zdrowotnych odgrywa szkoła, ochrona zdrowia, ale także grupy społeczno-kulturowe, wśród których funkcjonujemy [5].

Szczególną rolę w kształtowaniu wiedzy o zdrowiu oraz rozwijaniu umiejętności prozdrowotnych przypisuję się edukacji zdrowotnej oraz promocji zdrowia. Oba te procesy powinny towarzyszyć człowiekowi na każdym etapie jego rozwoju przy wsparciu odpowiednich profesjonalistów (tzw. life long learning) [6].

Ważnymi odbiorcami działań edukacyjnych stają się obecnie osoby dorosłe, aktywne zawodowo. $Z$ analiz statystycznych wynika, iż z roku na rok znacznie wzrośnie liczba osób starszych, która odzwierciedlać będzie nie tylko kondycję ekonomiczną naszego państwa, ale także kondycję zdrowotną społeczeństwa. Stan zdrowia osób aktywnych zawodowo determinuje zarówno ich jakość życia oraz zdolność do pełnego realizowania swoich ról rodzinnych, społecznych czy zawodowych $[6,7]$.

Sposób definiowania pojęcia zdrowie przez ludzi w ich codziennym funkcjonowaniu jest uwarunkowane różnymi czynnikami. Wpływ na definiowanie zdrowia mają: wiek, wykształcenie, sytuacja społeczno-ekonomiczna czy środowisko kulturowe życia i pracy [1].

Wybór tematu jest próbą uzupełnienia obecnego stanu wiedzy z zakresu badań, analizujących zachowania zdrowotne oraz znaczenie zdrowia wśród osób pracujących. Liczne publikacje, podejmujące problematykę zdrowia i ochrony zdrowia osób aktywnych zawodowo jedynie dowodzą, iż temat ten jest istotny z perspektywy medycznej, społecznej czy nawet gospodarczej. Biorąc pod uwagę niekorzystne prognozy demograficzne względem naszego społeczeństwa każde badanie, będące próbą przybliżenia profilu zdrowotnego osób aktywnych zawodowo, stanowić będzie istotny wkład na rzecz działań podtrzymujących czy wzmacniających potencjał zdrowotny osób dorosłych. 


\section{CEL PRACY}

Celem badań była ocena zachowań zdrowotnych oraz pozytywnych elementów wymiarów zdrowia fizycznego, psychicznego i społecznego.

\section{MATERIAŁ I METODY}

Badanie przeprowadzono w miesiącach luty- marzec 2018 roku w Niepublicznym Zakładzie Opieki Zdrowotnej na terenie województwa świętokrzyskiego. W badaniu zastosowano losowy dobór próby. Efektem doboru próby było włączenie do badania osób aktywnych zawodowo, reprezentujących różne grupy wiekowe oraz poziom wykształcenia. które zgłosiły się na badania okresowe do Poradni Medycyny Pracy w wyżej wymienionej placówce zdrowotnej. W kolejnym etapie badań respondenci zostali poproszeni o wypełnienie ankiety po uprzednim wyjaśnieniu celu badań. Każdy z badanych osób został poinformowany o anonimowości badań oraz o tym, iż badania mają charakter naukowo-badawczy i takim celom wyłącznie służą. Łącznie rozdano 130 ankiet. Odsetek zwrotów wyniósł 101. Powodem odrzucania ankiet były nieprawidłowe, nieczytelne bądź niepełne wypełnienie kwestionariusza. Dane dotyczące wieku, płci oraz wykształcenia przedstawiono w tabeli 1 .

W celu oceny zachowań zdrowotnych osób pracujących w badaniu wykorzystano kwestionariusz standaryzowany Inwertarz Zachowań Zdrowotnych (IZZ) autorstwa Z. Juczyńskiego [8]. W tym celu uzyskano od Pracowni Testów Psychologicznych zgodę na zakup licencji i wykorzystanie narzędzia IZZ w badaniach własnych. Narzędzie to zawiera 24 stwierdzenia, opisujące różne zachowania zdrowotne. Na podstawie wskazanej przez respondentów częstotliwości poszczególnych zachowań ocenić można nasilenie zachowań, które wzmacniają zdrowie oraz stopień nasilenia czterech kategorii zachowań zdrowotnych:

- prawidłowych nawyków żywieniowych,

- zachowań profilaktycznych,

- praktyk zdrowotnych,

- pozytywnego nastawienia psychicznego.

\section{Tab. 1. Charakterystyka grupy badanej}

\begin{tabular}{|c|c|c|c|c|c|c|c|c|}
\hline \multirow{2}{*}{ L.p. } & \multirow{2}{*}{\multicolumn{2}{|c|}{ Analizowane zmienne }} & \multicolumn{2}{|c|}{ Kobiety } & \multicolumn{2}{|c|}{ Mężczyźni } & \multicolumn{2}{|c|}{ Razem } \\
\hline & & & N & $\%$ & N & $\%$ & $\mathbf{N}$ & $\%$ \\
\hline 1 & \multicolumn{2}{|c|}{ Płeć/ sex } & 49 & 48,5 & 52 & 51,5 & 101 & 100,0 \\
\hline \multirow{6}{*}{2} & \multirow{6}{*}{ Wiek } & $18-29$ & 14 & 28,6 & 8 & 15,4 & 22 & 21,8 \\
\hline & & $30-39$ & 15 & 30,6 & 23 & 44,2 & 38 & 37,6 \\
\hline & & $40-49$ & 17 & 34,7 & 12 & 23,1 & 29 & 28,7 \\
\hline & & $50-59$ & 3 & 6,1 & 9 & 17,3 & 12 & 11,9 \\
\hline & & $>60$ & 0 & 0.0 & 0 & 0.0 & 0 & 0.0 \\
\hline & & Razem & & 100 & & 100 & & 100 \\
\hline \multirow{5}{*}{3} & \multirow{5}{*}{ Wykształcenie } & Podstawowe & 0 & 0 & 2 & 3,8 & 2 & 2,0 \\
\hline & & Średnie & 11 & 22,4 & 11 & 21,2 & 22 & 21,8 \\
\hline & & $\begin{array}{c}\text { Średnie } \\
\text { zawodowe }\end{array}$ & 11 & 22,4 & 19 & 36,5 & 30 & 29,7 \\
\hline & & Wyższe & 27 & 55,1 & 20 & 38,5 & 47 & 46,5 \\
\hline & & Razem & & 100 & & 100 & & 100 \\
\hline
\end{tabular}

Źródło: badania własne
W celu poznania opinii na temat wartości zdrowia wśród osób aktywnych zawodowo zastosowano standaryzowany kwestionariusz LKZ - Lista Kryteriów Zdrowia autorstwa Z. Juczyńskiego [8]. W tym celu uzyskano od Pracowni Testów Psychologicznych zgodę na zakup licencji i wykorzystanie narzędzia LKZ w badaniach własnych. Narzędzie badawcze zawiera 24 pozytywne stwierdzenia, odnoszące się do trzech wymiarów zdrowia: fizycznego, psychicznego oraz społecznego. Respondenci zaznaczają swe wybory, wskazując jednocześnie, które ze stwierdzeń są dla nich ważne w ocenie zdrowia. Na koniec badania respondent musi uszeregować twierdzenia według ważności od najważniejszych do najmniej ważnych.

\section{WYNIKI}

W badaniach wzięło udział 101 osób. Kobiety stanowiły 48,5\% badanej grupy $(\mathrm{n}=49)$ zaś mężczyźni 51,5\% $(\mathrm{n}=52)$. Największy odsetek badanych osób stanowiły osoby w wieku $30-39$ lat $(37,6 \%, \mathrm{n}=38)$ oraz $40-49$ $(28,7 \%, n=29)$. Najmniejszą grupą byli badani w wieku powyżej 60 roku życia $(11,9 \%, n=12)$. W badanej grupie dominowały osoby z wykształceniem wyższym (46,5\%, $\mathrm{n}=47)$ oraz średnim-zawodowym $(29,7 \%, \mathrm{n}=30)$. Zaledwie 2 osoby spośród badanych deklarowały posiadanie wykształcenia podstawowego.

Analizy statystyczne z przeprowadzono wykorzystaniem oprogramowania IBM SPSS Statistics 23. Za poziom istotności w badaniu przyjęto $\mathrm{p}<0,005$.

W pierwszym etapie badania postanowiono określić związek między nasileniem deklarowanych przez badanych zachowań zdrowotnych, a poziomem ich wykształcenia, grupy wiekowej oraz płci. Uzyskano wyniki istotne statystycznie dla efektów głównych wszystkich zmiennych: płeć: $\mathrm{p}=0,029$, grupa wiekowa: $\mathrm{p}<0,001$, wykształcenie: $\mathrm{p}=0,003$.

Analiza badań wykazała, iż kobiety osiągnęły istotnie wyższe wyniki $(\mathrm{p}<0,001)$ w skali IZZ niż mężczyźni. Nie działo się tak jednak we wszystkich grupach wiekowych i nie u osób z każdym wykształceniem. Jak wynika z badań w grupie osób w wieku 18-29 lat z wykształceniem średnim oraz w grupie osób w wieku 50-59 lat z wykształceniem wyższym to mężczyźni uzyskiwali wyższe wyniki na skali IZZ (odpowiednio $\mathrm{p}=0,035$ i $\mathrm{p}=0,009)$.

Najniższe wyniki na skali IZZ uzyskali mężczyźni w wieku 40-49 lat $\mathrm{z}$ wykształceniem wyższym oraz podstawowym. Ponadto zaobserwowano, iż w grupie osób starszych (grupa wiekowa 50-59 lat) zdecydowanie najwyższe wyniki uzyskano wśród osób z wykształceniem wyższym. Zauważono również, iż osoby w wieku 18-29 lat oraz w wieku 50-59 lat prezentowały zdecydowanie najwyższe wyniki. Były one istotnie wyższe (odpowiednio $\mathrm{p}=0,041$ i p $<0,001$ ) od wyników uzyskanych w grupie wiekowej 30-39 lat. Wyniki zebrano w Tabeli 2.

Ponadto jak wynika z badań, silną determinantą zachowań zdrowotnych jest wykształcenie badanych osób. Zarówno kobiety jak i mężczyźni z wykształceniem wyższym nie różnią się między sobą w zakresie deklarowanych prawidłowych nawyków żywieniowych. Różnice 
te widoczne są natomiast wśród osób z niższym wykształceniem. Ponadto kobiety niezależnie od poziomu wykształcenia częściej uczestniczą w badaniach profilaktycznych $(\mathrm{p}<0,001)$ oraz realizują praktyki zdrowotne $(\mathrm{p}=0,048) \mathrm{w}$ przeciwieństwie do mężczyzn.

W badaniach dowiedziono, iż zarówno kobiety jak i mężczyźni prezentują jednakowy poziom zachowań w zakresie nastawienia psychicznego. Wyniki przedstawiono w Tabeli 3.

Kolejnym etapem badań było poznanie opinii na temat znaczenia zdrowia wśród osób aktywnych zawodowo. Analiza wyników badań wykazała, iż najczęściej zdrowie definiowane jest jako stan, właściwość oraz cel. Badani niezależnie od płci, wieku oraz wykształcenia uznali stwierdzenie - „Czuję się szczęśliwy przez większość

Tab. 2. Wyniki średnie zachowań zdrowotnych u kobiet i mężczyzn w zależności od wykształcenia i wieku

\begin{tabular}{|c|c|c|c|}
\hline Wiek & Wykształcenie & Kobiety & Mężczyżni \\
\hline & & Mediana/M & Mediana/M \\
\hline \multirow{4}{*}{$18-29$} & Podstawowe & & \\
\hline & Średnie & 81 & 97,5 \\
\hline & Zawodowe & & 82 \\
\hline & Wyższe & 87,9 & 95 \\
\hline \multirow{4}{*}{$30-39$} & Podstawowe & & \\
\hline & Średnie & 86,33 & 63 \\
\hline & Zawodowe & 97,33 & 71,25 \\
\hline & Wyższe & 86,44 & 79,69 \\
\hline \multirow{4}{*}{$40-49$} & Podstawowe & & 49 \\
\hline & Średnie & 78,2 & 72,5 \\
\hline & Zawodowe & 88,4 & 74,5 \\
\hline & Wyższe & 92 & 47 \\
\hline \multirow{4}{*}{$50-59$} & Podstawowe & & \\
\hline & Średnie & & 74 \\
\hline & Zawodowe & 87,5 & 81,6 \\
\hline & Wyższe & 90 & 119 \\
\hline
\end{tabular}

Źródło: badania własne czasu” oraz „Nie odczuwać żadnych dolegliwości fizycznych" za ważne, jeśli chodzi o sposób interpretowania pojęcia zdrowie.

W dalszej kolejności sprawdzono czy badani w zależności od wieku, płci i wykształcenia różnili się między sobą sposobem definiowania zdrowia poprzez takie określenie jak - „Nie chorować, co najwyżej rzadko na grypę lub niestrawność”. W tym przypadku uzyskano wynik istotny statystycznie dla efektu głównego zmiennej wykształcenie $(\mathrm{p}=0,008)$. Zdrowie rozumiane jako „brak chorób” było istotnie statystycznie częściej deklarowane przez osoby $\mathrm{z}$ wykształceniem zawodowym $(\mathrm{p}=0,006)$ niż przez osoby z wykształceniem wyższym (Rycina 1). Ponadto można stwierdzić, iż w grupie wiekowej 30-39 lat to mężczyźni ( $\mathrm{p}=0,005)$ bardziej niż kobiety postrzegają zdrowie jak stan bez chorób. Odmienną sytuację obserwujemy zaś w grupie osób 40 - 49 lat. W tej grupie wiekowej, to kobiety $(\mathrm{p}=0,003)$ bardziej niż mężczyźni postrzegają zdrowie jak okres życia bez chorób (Rycina 2).

Badani uznali także, iż ważne w definiowaniu zdrowia jest określenie nawiązujące do sprawności wszystkich części ciała (jest to 20 stwierdzenie LKZ). Stwierdzenie

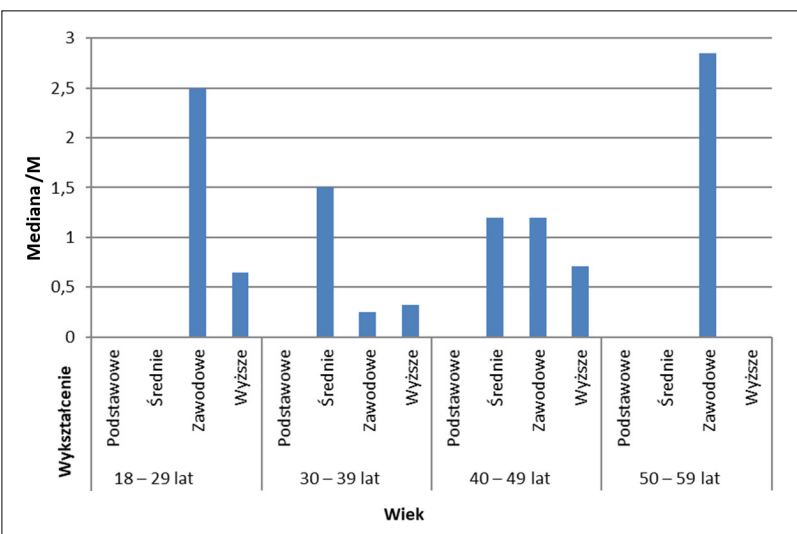

Ryc 1. Postrzeganie braku chorób jako właściwości zdrowia przez badanych w zależności od wykształcenia i wieku

Źródło: badania własne

Tab. 3. Wyniki średnie zachowań zdrowotnych w zależności od płci oraz wykształcenia badanych

\begin{tabular}{|c|c|c|c|c|c|c|c|}
\hline \multirow{2}{*}{\multicolumn{2}{|c|}{$\begin{array}{l}\text { Zachowania } \\
\text { zdrowotne }\end{array}$}} & $\begin{array}{c}\text { IZZ } \\
\text { / inwertarz } \\
\text { zachowań } \\
\text { zdrowotnych }\end{array}$ & $\begin{array}{c}\text { PNŻ } \\
\text { (prawiodłowe } \\
\text { nawyki } \\
\text { żywieniowe) }\end{array}$ & $\begin{array}{c}\text { ZP } \\
\text { (zachwania } \\
\text { profilaktyczne) }\end{array}$ & $\begin{array}{c}\text { PNP } \\
\text { (pozytywne } \\
\text { nastawienie } \\
\text { psychiczne) }\end{array}$ & $\begin{array}{c}\text { PZ } \\
\text { (praktyki } \\
\text { zdrowotne) }\end{array}$ & Razem \\
\hline & & Mediana / M & Mediana / M & Mediana / M & Mediana / M & Mediana / M & \\
\hline \multirow{5}{*}{$\frac{\overrightarrow{\mathrm{d}}}{\frac{\overline{0}}{0}}$} & Podstawowe & & & & & & \\
\hline & Średnie & 5,00 & 3,43 & 3,46 & 3,36 & 3,28 & 18,53 \\
\hline & Zawodowe & 6,50 & 4,03 & 3,68 & 4,18 & 3,25 & 21,64 \\
\hline & Wyższe & 6,11 & 3,78 & 3,63 & 3,82 & 3,53 & 20,87 \\
\hline & Razem & 17,61 & 11,24 & 10,77 & 11,36 & 10,06 & 61,04 \\
\hline \multirow{5}{*}{ 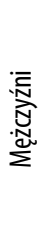 } & Podstawowe & 1,00 & 1,83 & 2,17 & 2,17 & 2,00 & 9,17 \\
\hline & Średnie & 5,00 & 2,89 & 3,02 & 3,65 & 3,03 & 17,59 \\
\hline & Zawodowe & 5,21 & 2,95 & 2,83 & 3,88 & 2,97 & 17,84 \\
\hline & Wyższe & 6,30 & 3,48 & 3,37 & 4,01 & 3,32 & 20,48 \\
\hline & Razem & 17,51 & 11,15 & 11,39 & 13,71 & 11,32 & 65,08 \\
\hline
\end{tabular}


to okazało się być zdecydowanie bardziej ważniejsze dla osób w starszych grupach wiekowych w porównaniu z osobami w wieku 18-29 lat. Ponadto właściwość ta jest częściej deklarowana przez badanych z wykształceniem średnim bądź średnim-zawodowym w stosunku do osób z wykształceniem wyższym (Rycina 3). Postrzeganie sprawności wszystkich części ciała, jako właściwości charakteryzującej zdrowie jest różne wśród kobiet i mężczyzn z grupy wiekowej 30-39 lat. Kobiety bowiem w tej grupie wiekowej statystycznie bardziej $(\mathrm{p}=0,002)$ niż mężczyźni postrzegają stwierdzenie nr $20 \mathrm{LKZ}$ jako ważne dla oceny właściwości zdrowia.

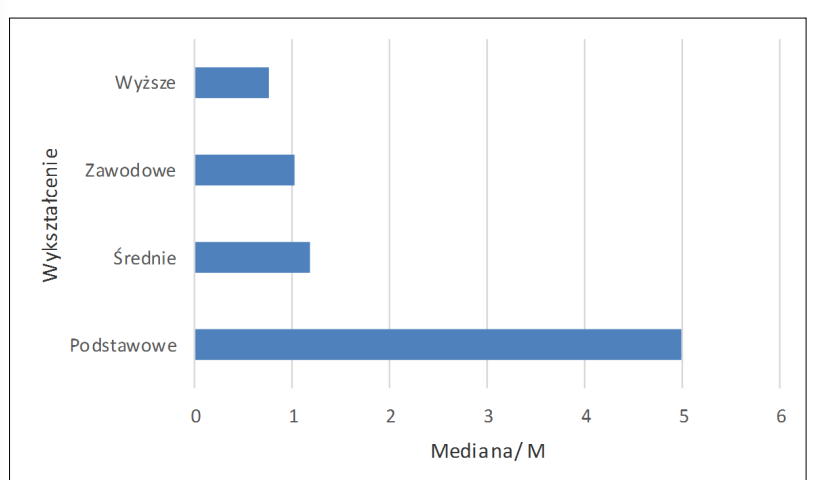

Ryc 2. Postrzeganie braku chorób jako właściwości zdrowia u kobiet i mężczyzn w zależności od ich grupy wiekowej

Źródło: badania własne

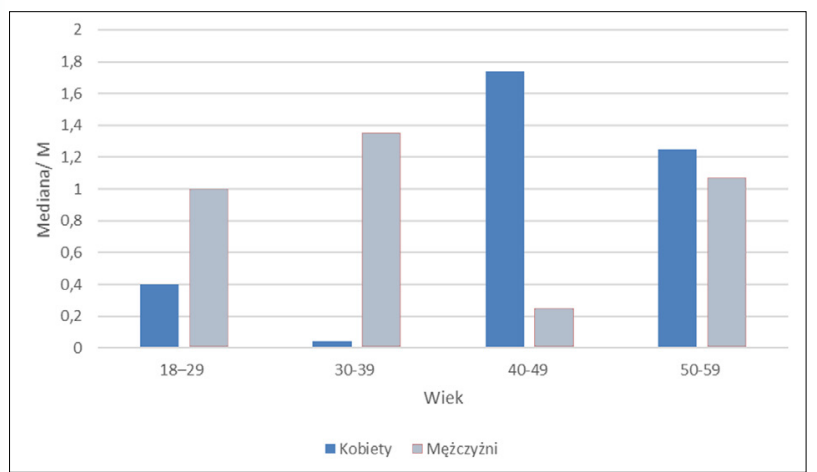

Ryc 3. Postrzeganie sprawności wszystkich części ciała jako właściwości zdrowia przez badanych zależności wykształcenia i wieku

Źródło: badania własne

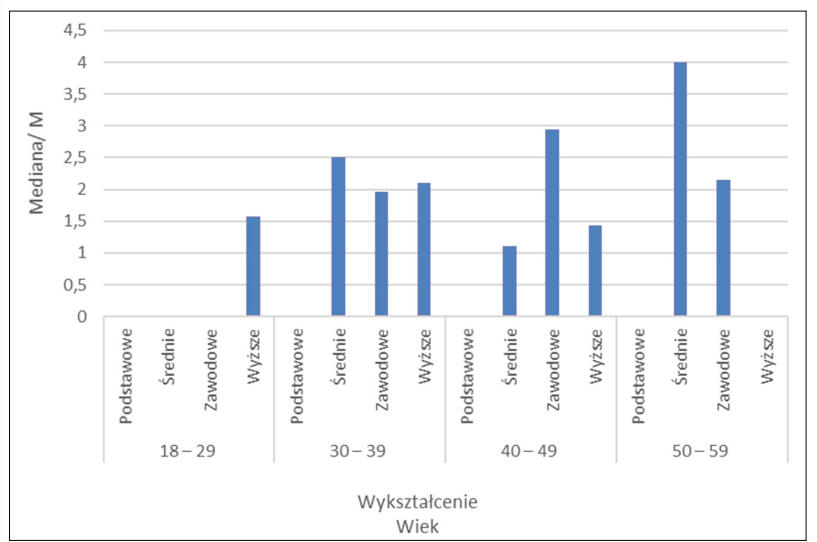

Ryc 4. Ważność dobrego samopoczucia jako stanu definiującego zdrowie w ocenie badanych w zależności od ich wykształcenia

Źródło: badania własne
W badaniu wykazano również, iż wykształcenie badanych wpływa na sposób definiowania zdrowia poprzez właściwość - „Czuć się dobrze”. Osoby z wykształceniem podstawowym $(\mathrm{M}=1,03)$ częściej określają zdrowie jako stan, w którym czują się po prostu dobrze w porównaniu z osobami z wykształceniem średnim $(M=1,18)$, zawodowym $(M=1,03)$ czy wyższym $(M=0,75)$. Wyniki przedstawiono na Rycinie 4.

\section{DYSKUSJA}

Określenie czym dla człowieka jest „być zdrowym” bywa czasem trudne i niejednoznaczne. Sposób definiowania i wartościowania zdrowia jest uwarunkowany między innymi wiekiem, płcią, wykształceniem oraz innym czynnikami społecznymi, kulturowymi czy religijnymi. Obecnie szacuje się, że definicji zdrowia jest około 120. Głównym problemem pojęcia „zdrowie” jest fakt, iż sposób definiowania jest uzależniony od celów, okoliczności bądź intencji samych twórców. Różnice w sposobie definiowania zdrowia wynikają także z licznych uwarunkowań zdrowia w tym społeczno-kulturowych czy społeczno-ekonomicznych. Próba wartościowania oraz nowego zdefiniowania zdrowia, pojawia się najczęściej w momencie choroby czy niepełnosprawności. Zachowania zdrowotne, które determinują nasz stan zdrowia fizycznego i psychicznego nabierają wówczas nowego znaczenia [9].

Wyniki przeprowadzonych badań własnych wskazują, iż kobiety osiągnęły wyższe wyniki w skali IZZ niż mężczyźni. Ponadto ważną determinantą zachowań zdrowotnych okazało się wykształcenie osób pracujących. Badani z wykształceniem podstawowym prezentują bowiem niższy poziom zachowań zdrowotnych w stosunku do osób z wykształceniem wyższym.

Odmienne wyniki w stosunku do badań własnych uzyskano w badaniach Arendt A i wsp. [10], w których analizowano zachowania zdrowotne mężczyzn po 40 roku życia. Jak wynika z powyższych badań wykształcenie nie wpływa w istotny sposób na prezentowane przez mężczyzn zachowania zdrowotne, a poziom ich zachowań zdrowotnych kształtuje się na poziomie przeciętnym. Również w badaniach przeprowadzonych w 2016 roku wśród pacjentów korzystających z Poradni Leczenia Otyłości, to mężczyźni częściej niż kobiety deklarowali praktyki związane z prawidłowym sposobem odżywiania. Odpowiednio u mężczyzn był to wynik przeciętny, zaś u kobiet niski [11].

Przeprowadzone w 2009 roku badania przez Andruszkiewicz A i wsp. wśród osób uzależnionych od nikotyny (w tym 104 mężczyzn, co stanowiło 47\% badanej grupy) wskazują na niski poziom deklarowanych zachowań zdrowotnych mężczyzn w przeciwieństwie do kobiet, co jest zbieżne z wynikami badań własnych [12]. Podobne wyniki uzyskano także w badaniach przeprowadzonych w Szpitalnym Oddziale Ratunkowym w Bydgoszczy, w którym hospitalizowani pacjenci płci męskiej uzyskali niższe wartości zachowań zdrowotnych aniżeli kobiety [13]. Również z badań przeprowadzonych wśród uczestników Uniwersytetu Trzeciego Wieku wynika, iż płeć determinuje 
zachowania zdrowotne. W badaniach Cieślak-Zadworna M oraz Ogińska-Bulik N. to kobiety w Inwertarzu Zachowań Zdrowotnych uzyskały wyższy wyniki zachowań zdrowotnych niż mężczyźni [14].

Odmienne wyniki w stosunku do badań własnych uzyskano w badaniach Kaczyńskiej-Witkowskiej A i wsp. Autorzy powyższych badań analizowali zachowania zdrowotne i postawy wobec zdrowia kobiet aktywnych fizycznie. Wyniki w skali IZZ dla kobiet przyjęły wówczas $\mathrm{w}$ badaniach poziom przeciętny [15].

W badaniach własnych zwrócono uwagę na korelację między płcią badanych, a poziomem zachowań zdrowotnych (kobiety częściej deklarują pozytywne zachowania zdrowotne). Wyniki te są zgodne $\mathrm{z}$ innymi doniesieniami, z których wynika, iż kobiety chętniej prezentują prozdrowotne zachowania, związane m.in ze zdrowszym sposobem odżywiania się [16].

Jak wynika z badań, oceniających zależności występujące pomiędzy poszczególnymi kategoriami zachowań zdrowotnych osób starszych, a zmiennymi socjo-demograficznymi, jedynie wykształcenie wpływa na obserwowane różnice $\mathrm{w}$ deklarowanych zachowaniach zdrowotnych. Podobnie jak w badaniach własnych, niski poziom zachowań zdrowotnych częściej obserwowany jest wśród osób z wykształceniem podstawowym [17].

Wyniki badań własnych donoszą, iż kobiety częściej niż mężczyźni realizują praktyki zdrowotne i uczestniczą w badaniach profilaktycznych. Podobne wyniki uzyskano w badaniach przeprowadzonych przez Grochans E i wsp. [18]. W przytoczonych badaniach kobiety dwukrotnie częściej deklarowały zachowania z zakresu praktyk zdrowotnych oraz profilaktycznych.

Również Borrell C i wsp w swoich badaniach zaobserwowali korelację między płcią badanych a zachowaniami zdrowotnymi. Autorzy badań, dokonując systematycznego przeglądu piśmiennictwa z okresu 1970-2012 roku wykazali , iż kobiety częściej prezentowały zachowania zdrowotne [19].

W piśmiennictwie wykształcenie opisywane jest jako czynnik silnie determinujący zachowania zdrowotne populacji [20-21].W artykule Ślusarskiej i Nowickiego wykształcenie wyższe koreluje $\mathrm{z}$ wyższym wskaźnikiem zachowań zdrowotnych, zaś osoby z wykształceniem podstawowym prezentują niski poziom zachowań zdrowotnych. Badania wskazują, że edukacja rozumiana jako proces długoterminowy oraz ciągły, wpływa na poziom wiedzy, a tym samym determinuje indywidualne zdolności kształtowania własnego zdrowia i zachowań zdrowotnych

Ponadto $\mathrm{w}$ badaniach własnych zaobserwowano wyższy poziom zachowań zdrowotnych wśród osób w wieku 18-29 lat oraz powyżej 50 roku życia. Bednarek A i wsp. [22] w badaniach przeprowadzonych w 2010 roku podjęli próbę analizy zachowań zdrowotnych dziewcząt i chłopców w wieku szkolnym. Z powyższych badań wynika, iż zarówno chłopcy jak i dziewczęta prezentują nieprawidłowe zachowania prozdrowotne, a zachowania związane ze złym odżywianiem się i niską aktywnością częściej występują wśród dziewcząt. Pomimo, iż w badaniach tych analizowana młodsze grupy wiekowe, to należy mieć na uwadze rolę edukacji zdrowotnej w okresie adole- scencji. Wzorce zachowań zdrowotnych nabytych w toku kształcenia podstawowego mogą mieć ogromne znacznie w budowaniu kondycji zdrowotnej w późniejszych latach. Zarówno szkoła jako instytucja oraz środowisko pracy odgrywają ważną role w kształtowaniu dobrych nawyków zdrowotnych oraz kreowaniu większej odpowiedzialności za własne zdrowie.

W badaniach Spring B i wsp. przeanalizowano ryzykowne zachowania zdrowotne wśród młodzieży i osób dorosłych. W badaniach tych zaobserwowano wzrost ryzykownych zachowań zdrowotnych w starszych grupach wiekowych w przeciwieństwie do badań własnych [23].

$\mathrm{Z}$ analizy badań własnych wynika, iż badani najwyższą wagę przypisują zdrowiu definiowanemu jako stan, właściwość oraz cel. Dla badanych bycie zdrowym oznacza czuć się dobrze, nie odczuwać żadnych dolegliwości bólowych, mieć sprawne wszystkie części ciała, akceptować siebie, znać swoje możliwości czy nie chorować.

Badania przeprowadzone przez Kozieł D i wsp. [24] oraz Naszydłowską E i wsp. [25] wśród studentów Świętokrzyskiej Szkoły Medycznej wskazują, iż badani zarówno płci męskiej jak i żeńskiej wysoko postrzegają zdrowie, które określane jest jako wartość i proces. Z powyższych badań wynika także, iż dla badanych studentów posiadanie sprawnych wszystkich części ciała jest najbardziej właściwym stanem, opisującym zdrowie. Również badania Piaseckiej H i wsp [26], oceniające wartość zdrowia w opinii społeczności studenckiej wykazały, iż osoby młode przywiązywały większą wagę do znaczenia stwierdzenia - „Mieć sprawne wszystkie części ciała”. Powyższe doniesienia są sprzeczne $\mathrm{z}$ wynikami badań własnych, w których to osoby starsze częściej deklarowały sposób definiowania zdrowia poprzez kategorię sprawności wszystkich części ciała.

Wyniki badań własnych wskazują, iż określenie „Nie chorować” jest szczególnie istotne w definiowaniu zdrowia dla osób posiadających niższe wykształcenie. Wyniki te są zbieżne z wynikami zaprezentowanymi przez Nowicki G. i Ślusarska B. [21]. Przeprowadzone przez zacytowanych autorów badania w roku 2008 w Wojewódzkim Ośrodku Medycyny Pracy w Lublinie wykazały, że dla osób $\mathrm{z}$ wykształceniem zasadniczym najważniejszym stanem, opisującym zdrowie jest stwierdzenie - „Nie chorować najwyżej rzadko na grypę lub niestrawność”. Z powyższych badań wynika także, iż osoby starsze (powyżej 50 roku życia) częściej wybierały stwierdzenie „Mieć sprawne wszystkie części ciała” jako określenie zdrowia w porównaniu z osobami młodszymi. Również w badaniach własnych zaobserwowano, iż to osoby starsze chętniej wybierały powyższe określenie w celu zdefiniowania zdrowia.

W badaniach własnych wykazano także, iż mężczyźni w wieku od 18 do 39 roku życia częściej w celu określenia wartości zdrowia wybierają stwierdzenie - „Nie chorować co najwyżej rzadko na grypę lub niestrawność”. Podobne wyniki uzyskane w badaniach przeprowadzonych przez Krajewska-Kułak E i wsp. [27]. Z zacytowanych badań przeprowadzonych wśród mężczyzn wynika, iż spośród 24 stwierdzeń Listy Kryteriów Zdrowia badani największą wagę przywiązywali do zdrowia rozumianego jako stan, kiedy nie chorują, bądź chorują rzadko. 
Jak wynika z badań własnych kobiety niezależnie od wieku i wykształcenia w jednakowy sposób przywiązują wagę do stwierdzenia „Nie odczuwać żadnych dolegliwości bólowych". Odmienne wyniki uzyskano w badaniach Delugi A i wsp, [28], w których analizowano sposób wartościowania zdrowia wśród pielęgniarek. Z wyników powyższych badań wynika, iż właściwość ta ściśle koreluje z wiekiem - im wyższy wiek, tym większa ranga powyższego stwierdzenia..

\section{WNIOSKI}

- Wykształcenie badanych osób jest główną determinantą zachowań zdrowotnych, które w istotny sposób wpływa na indywidulane umiejętności dbania o zdrowie oraz utrzymywania potencjału zdrowotnego.

- Kobiety, stanowią grupę osób aktywnych zawodowo, które prezentują wyższe wyniki zachowań zdrowotnych, częściej realizują praktyki zdrowotne i podejmują działania w zakresie profilaktyki zdrowia.

- Osoby starsze z niższym wykształceniem definiują zdrowie, jako zdolność funkcjonowania organizmu bez chorób.

\section{REFERENCES/PIŚMIENNICTWO}

1. Nowicki G, Ślusarska B. Socio-demographic determinants of health evaluation among working adults. Hygeia Public Health. 2011; 46(2): 280-285.

2. Synowiec-Piłat M. Paradygmat socjoekologiczny jako zaplecze teoretyczne promocji zdrowia. [w:] Synowiec-Piłat M. Marszałek \& AM, red. Promocja zdrowia i profilaktyka onkologiczna w działaniach organizacji pozarządowych. WrocławToruń; 2009, s.17-39.

3. Heszen I, Sęk H. red. Psychologia zdrowia. Warszawa: Wyd. PWN; 2008.

4. Malik M, Zarzycka D, Iłżecka J, Jarosz M. Wartość zdrowia jako czynnik motywacyjny do działań prozdrowotnych. Zdr Publ. 2009; 119(1): 33-39.

5. Duda-Zalewska A. Teachers 'health behaviors versus their professional seniority. Hygeia Public Health. 2012; 47 (2): 183-187.

6. Korzeniowska E. Polscy pracownicy o wykorzystywaniu nowych mediów w edukacji zdrowotnej i promocji zdrowia w miejscu pracy. Studia Edukacyjne. 2012; 23: 163181.

7. Gajdzik B. Worksite assistance and health promotion activites for employees over 50. Zeszyty Naukowe Wyższej Szkoły Zarządzania Ochrona Pracy w Katowicach. 2014; 1 (10): 91-103.

8. Juczyński Z. red. Narzędzia pomiaru w promocji i psychologii zdrowia. Warszawa: Wyd. Pracownia Testów Psychologicznych Polskiego Towarzystwa Psychologicznego; 2009.

9. Domradzki J. 0 definicjach zdrowia i choroby. Folia Medica Lodziensia. 2013;40 (1): $5-29$.

10. Arendt A, Laszczyńska M, Bażydło M, i wsp. Ocena zachowań zdrowotnych mężczyzn po 40 roku. Probl Hig Epidemiol. 2014; 95(3): 659-666.

11. Sekuła M, Boniecka I, Paśnik K. Ocena zachowań zdrowotnych, żywieniowych i poczucie własnej skuteczności chorych z otyłością olbrzymią. Psychiatr. Pol. 2018; 105: 1-13.

12. Andruszkiewicz A, Basińska M. Zachowania zdrowotne osób uzależnionych od nikotyny. Prz Lek. 2009; 66 (10): 783-797.

13. Kurowska K, Białasik B. Zachowania zdrowotne a radzenie sobie w chorobie u pacjentów Szpitalnego Oddziału Ratunkowego (SOR). Now Lek. 2009;2 (78): 113122.

14. Cieślak-Zadworna M, Ogińska-Bulik N. Zachowania zdrowotne osób w wieku senioralnym - rola optymizmu. Psychoterapia Polska. 2013;10 (4):145-156.

15. Kaczyńska-Witkowska A, Kopeć D, Nowak Z. Zachowania Zdrowotne oraz postawa wobec zdrowia kobiet aktywnych fizycznie. Rozprawy Naukowe Akademii Wychowania Fizycznego we Wrocławiu. 2013;43: 22 - 28.

16. Ostrowska L, Karczewski J, Szwarc J. Sposób żywienia jako jeden z czynników środowiskowych nadwagi i otyłości. Rocz Państ Zakł Hig. 2007;58 (1): 307-313.
17. Sygit-Kowalewska E. Zachowania zdrowotne osób w okresie póżnej dorosłości socjodemograficzne korelaty i różnice między środowiskami społecznymi. Roczniki Pomorskiej Akademii Medycznej w Szczecinie. 2013;5 9(1): 103-113.

18. Grochans E, Gburek D i wsp. Ocena zachowań zdrowotnych pacjentów $z$ uwzględnieniem zmiennych socjodemograficznych. Family Medicine \& Primary Care Review. 2012;14 (2): 148-150.

19. Borrell C, Palència L, Muntaner Ci wsp. Influence of macrosocial policies on women's health and gender inequalitiesin health. Epidemiol Rev. 2014; 36: 31-38.

20. Szklarska A, Rogucka E. An assessment of biological age of males in Poland. Ann Hum Biol. 2001; 28, 30 .

21. Ślusarska B, Nowicki G. Zachowania zdrowotne w profilaktyce chorób układu krążenia wśród osób pracujących. Probl Hig Epidemiol. 2010;91 (1): 34-40.

22. Bednarek A, Bednarz M. Zachowania zdrowotne chłopców i dziewcząt w młodszym wieku szkolnym. Medycyna Ogólna i Nauki o Zdrowiu. 2013; 19 (3): 305-312.

23. Spring B, Moller AC, Coons M. J. Multiple health behaviours: overview and implications. Public Health (0xf). 2012;34 (1): 3-10.

24. KoziełD, Naszydłowska E, Trawczyńska M i wsp. Zachowania zdrowotne młodzieży - kierunek działań dla edukacji zdrowotnej. Zdr Publ. 2003;113 (3/4): 280-284.

25. Naszydłowska E, Krawczyńska J, Kozieł D, i wsp. Wartościowanie zdrowia, a zachowania promujące zdrowie studentów. Ann UMCS. 2005; LX(XVI) 349: 62-66.

26. Piasecka H, Ślusarska B, Nowicki G. Zdrowie jako wartość wśród młodzieży studenckiej w uwarunkowaniach społeczno-demograficznych i ocena żywienia badanej grupy. Pielęgniarstwo Polskie. 2015;2 (56):127134.

27. Łapińska M, Krajewska-Kułak E, Okurowska-Zawada B. Aktywność fizyczna i preferencje zdrowotne w grupie mężczyzn pracujących fizycznie lub umysłowo. Piel Zdr Publ. 2015;3: 253-264.

28. Deluga A, Dobrowolska B, Kosicka B, Brzozowska A. Health evaluation with relation to socio-demographic variables - nurses' opinions. Journal of Education, Health and Sport. 2016;6 (4):167-180.

Manuscript received/Praca zgłoszona do czasopisma: 25.02.2019

Manuscript accepted/Praca zaakceptowana do druku: 26.06.2019

Translation/Tłumaczenie: Biuro tłumaczeń Mateusz Fatek Sp. z o.o. 